\title{
Management of Ekakushta, with special reference to Psoriasis, through Panchakarma: A Case Study
}

\author{
Case Report
}

\section{Kritika Thakur1, Sangeeta H Toshikhane2*, Mahesh M P3, Devyani Sanghani1}

\author{
1. PG scholar 2. Professor and HOD, 3. Assistant Professor, Department of Panchakarma,
} Parul University, Parul Institute of Ayurveda, Vadodara, Gujarat, India.

\begin{abstract}
In Ayurveda all the skin diseases have been discussed under the 'Vyadhi Kushtha' Ekakushtha is one among Kshudra Kushtha. Kshudra are the Vyadhis which do not cause any major systemic involvement but their appearance disturbs mental condition of the patient as the disease doesn't leave patient easily. They are not easy to treat as recurrence rate is very high. The clinical feature of Ekakushtha described represents remission, relapse and seasonal variation which are also present in Psoriasis. Modern medical science treats Psoriasis with PUVA, corticosteroids etc. But these therapies give serious side effects like hepatic and nephrotoxicity, bone marrow depression etc. Hence, it is the need of time to find out safe and effective treatment for Psoriasis and here Ayurveda plays an important role. Treatment modality of Ayurveda provides long lasting results and a better life to patients through its three basic principles i.e. Shodhana, Shamana and Nidan Parivarjana. Here we are reporting a 50-yearold female patient having symptoms of Ekakushtha since last 4 years. She was suffering from large round erythematous scaly patches over her B/L knee and elbow joint and also severe itching and dryness over affected lesions. There was no such significant past history of any other chronic illness. The patient was treated with Panchkarma i.e Vamana karma followed by Oral medications. Patient reported symptomatic improvement after the course of Vamana Karma.
\end{abstract}

Key Words: Panchkarma, Vaman, Ekakushtha, Shodhana, Psoriasis, Bio-Purification, Emesis Therapy.

\section{Introduction}

Human skin is considered, as the largest organ of the integumentary system, it is also the vehicle for the biological and social communication to the external world. Skin reflects our emotions and some aspects of normal physiology. Any deformity or disease condition of the skin leads to both physiological and psychological disturbance of the patient (1). Nowadays skin disease is very common. It is more prevalent in tropical and subtropical countries like India where the heat and humidity are high for most part of the year. It is too common and easy to underestimate the impact of skin diseases in patients. In most person healthy skin plays a major role and is a key component of the image they present to the outside world. Conversely those with skin disease are often stigmatized, due to appearance they belief is a result of a contagious disease (2). Nowadays consumption of junk food, fast food, cold drinks, smoking and drinking alcohol are increasing. There is a development of metabolic disorders like heart disease, diabetes mellitus, Renal diseases and skin

* Corresponding Author: Sangeeta H Toshikhane

Professor and HOD,

Department of Panchakarma,

Parul University, Parul Institute of Ayurveda,

Vadodara, Gujarat, India..

Email Id: drsangeetaj@gmail.com disease. Among these, Skin diseases can adversely affect almost every aspect of person's life. It may lead the person to have low-esteem, depression and embarrassment.

The name Panchkarma literally means "Five Actions" namely Vaman (Emesis), Virechan (Purgation), Niruham (therapeutic decoction enema) Anuvaasan (therapeutic oily Enema) and Nasyam (therapeutic errhine). In other words, Panchakarma is a healing technique or a pillar on which majority of Ayurvedic techniques stand. In Ayurveda all the skin diseases have been discussed under the Vyadhi "Kushtha" Ekakushtha (Psoriasis) is one among Kshudra-Kushtha. Nearly all Acharyas have described Ekakushtha first in their 11 types.

Symptoms of Ekakustha are:

Mahavastu (Large area), Mandaloutpati (Patches), Rukshata (Dryness), Matsyashakalopamam (silvery scales). Ekakushtha (Psoriasis) has dominancy of Kapha-vatadoshas (3). So clinically it can be correlated with Psoriasis.

Psoriasis is a skin disease which affects the 0.44 - 2.8\% of the Indian population. Treatment of Psoriasis may fall in 3 categories- Topical applications, systemic medications and Light therapy(4). But these treatments come with lots of side effects, such as joint pain, hair loss, loss of appetite, kidney damage and the major one is Carcinoma. Here Ayurveda plays an important role, i.e. Ek-kustha being Kapha Pradhana, Tridoshaja Vyadhi is best treated by Shodhan procedure (5). 
Shodhana Chikitsa forms the mainstay of treatment for all major skin diseases in Ayurveda which helps to remove the deep seated Dosha's from the root itself. Here in this study Vamana Karma is planned because it helps to eliminate deep seated Dosha from the body. In Ayurveda line of treatment both Shamana and Shodhana are available. As Ekakushtha is Bahudoshaja Vyadhi, Punah -Punah Shodhana can be done to avoid recurrence (6).

\section{Case Study}

A 50-year-old female patient registered by the O.P.D. number 20005596 on the date of 03/03/2020 came to the O.P.D. no. 105 of Parul Ayurveda Hospital and got admitted in Panchakarma Department, with IPD number 200769. She presented herself with the following complaints,

- Scaly Patches (Matsyashakalopamam) over B/L knee joint and $\mathrm{B} / \mathrm{L}$ elbow joint with red demarcation with Mandalotpatti.

- Severe itching, which would rarely result into bleeding.

- Dryness.

- Itching aggravating during night.

- Suffering from the last 4 years.

- Had taken modern treatment with limited improvement and recurrence.

Associated complaints- Irregular evacuation of stools.

\section{Past History}

- No H/O- DM, HTN, Surgical Procedures.

- No F/H/O- Any skin disorder

On Examination

- General condition: Moderate

- Pulse rate: $78 / \mathrm{min}$

- B.P: $130 / 90 \mathrm{~mm}$ of $\mathrm{Hg}$

- R.R: $17 / \mathrm{min}$

- H.R: $70 / \mathrm{min}$

\section{Ashta Sthana Pariksha}

\begin{tabular}{|l|l|l|}
\hline \multirow{2}{*}{ Nadi } & $\begin{array}{l}\text { VP: } \\
\text { VK: Vata Kaphaj } \\
\text { PK: } \\
\text { VPK: }\end{array}$ \\
\hline 2 & Mala & $\begin{array}{l}\text { Normally formed stool: Normal } \\
\text { Hard stools: } \\
\text { Loose stools: }\end{array}$ \\
\hline 3 & Mutra & $\begin{array}{l}\text { Prakrita: } \text { Prakrita } \\
\text { Vikrita: }\end{array}$ \\
\hline 4 & Jihva & $\begin{array}{l}\text { Alipta: } \text { Alipita } \\
\text { Isthalipta: } \\
\text { Lipta: }\end{array}$ \\
\hline 5 & Sabda & $\begin{array}{l}\text { Prakrita: } \text { Prakrita } \\
\text { Vikrita: }\end{array}$ \\
\hline 6 & Sparsha & $\begin{array}{l}\text { Mrudu: } \text { Mrudu } \\
\text { Khara: }\end{array}$ \\
\hline 7 & Druk & $\begin{array}{l}\text { Prakrita: } \text { Prakrita } \\
\text { Aprakrita: }\end{array}$ \\
\hline 8 & Akriti & $\begin{array}{l}\text { Sthula: } \\
\text { Madhyama:Madhyam } \\
\text { Heena: }\end{array}$ \\
\hline
\end{tabular}

Systemic examination

- Respiratory System: B/L Chest clear,Airway entry, Breathing entry Clear

- Cardiovascular System: - S1 S2 heard.

- CNS: All superficial reflexes are intact. Patient is conscious and well oriented.

- GIT: Soft Abdomen, Bowel sound heard, No Pain or any other symptoms

\section{Skin examination:}

\begin{tabular}{|l|l|l|}
\hline Chief complaints & Present & Absent \\
\hline Aswedanm & & - \\
\hline Mahavastum (area) & & - \\
\hline Matsyasaklopam & +++ & \\
\hline Kandu & ++++ & - \\
\hline Pidaka & & - \\
\hline Daha & & \\
\hline Vaivarnya & +++ & \\
\hline Rukashata & +++ & \\
\hline
\end{tabular}

TABLE-1: History of Present Illness

\begin{tabular}{|c|c|c|c|c|c|}
\hline Onset & S & $\mathbf{2}$ & $\mathbf{3}$ & $\mathbf{4}$ & $\mathbf{5}$ \\
\hline Chronicity & Acute & $\begin{array}{c}\text { Sub- } \\
\text { acute }\end{array}$ & Chronic & & \\
\hline Course & Progressive & $\begin{array}{c}\text { Inter- } \\
\text { mittent }\end{array}$ & & & \\
\hline $\begin{array}{c}\text { Provoking } \\
\text { Factor }\end{array}$ & Summer & Winter & Sunlight & Rainy & $\begin{array}{c}\text { Water } \\
\text { contact }\end{array}$ \\
\hline $\begin{array}{c}\text { Relieving } \\
\text { Factor }\end{array}$ & Summer & Winter & Sunlight & Rainy & $\begin{array}{c}\text { Water } \\
\text { contact }\end{array}$ \\
\hline
\end{tabular}

- Shape - Irregular Scaly Patches

- Size - Multiple Patches, no specific size. (Ranging from $7 \mathrm{~mm}$ to $10 \mathrm{~cm}$ too)

- Site- B/L knee joint and elbow joint

- Auspitz sign - 2

- Candle grease sign - 1

- PASI Scoring - 6.6 (7)

\section{Samprapti Ghatak}

- Dosha- Kapha Pradhana Vata Anubandhi

- Dushya-Rasa, Rakta, Mamsa, Ambu

- Srotas- Rasavaha, Raktavaha, Mamsavaha, Svedavaha

- Srotodushti- Sanga

- Ama-Sama

- Udbhavasthana-Amashaya

- Vyaktisthana-B/L knee joints and elbow joints.

\section{Treatment protocol:}

After proper clinical examination, patient was diagnosed with EkaKushtha and was advised to undergo Vamana Karma. i.e.

\section{A.: Purva Karma}

- Deepana Pachana: Trikatu Choorna -3gm thrice a day, before food with luke warm water was given until Nirama Lakshana appears, there after the patient was given Snehapana.

- Snehapana: Shodhananga Snehapana with Somaraji Ghrita given to the patient in increasing dose pattern, until Samyak Snigdha Lakshana appears, i.e. from 10/03/2020 - 13/03/2020 Snehapana administered and 
daily Jiryamana and Jirna Lakshana of Snehapana noted.

\section{Table 2: Schedule of Snehapana}

\begin{tabular}{|l|l|l|l|} 
Date & Time & Dose & Time of Hunger \\
\hline $10 / 3 / 2020$ & $7 \mathrm{AM}$ & 30ML & $12: 30 \mathrm{PM}$ \\
\hline $11 / 3 / 2020$ & $7: 10 \mathrm{AM}$ & 60ML & $2 \mathrm{PM}$ \\
\hline $12 / 3 / 2020$ & $7 \mathrm{AM}$ & 90ML & $2: 30 \mathrm{PM}$ \\
$13 / 3 / 2020$ & $6: 45 \mathrm{AM}$ & $120 \mathrm{ML}$ & $2: 45 \mathrm{PM}$ \\
\hline
\end{tabular}

-Vishrama Kala: On 14/03/2020, Abhyanga with Murchita Tila Tail followed by Aatapa Sweda was done for 1 day and Kaphautkleshta Ahara was given to the patient.

- Pradhana Karma: Vamana Karma with Madhanphala Pippali Yoga administered to the patient, i.e.

- On 15/03/2020, Vamana Karma day, first Abhyanga with Murchita Tila Taila and Ushna Jala Snana was given to the patient. The patient was told and counselled regarding the procedure and Patient sign was taken on informed Consent Form.

- At first Blood Pressure (130/90 mm of $\mathrm{Hg}$ ) and Pulse Rate (74/min) was monitored. Then Yavagu ( 70 to $120 \mathrm{gm}$ ) was given to patient just after the bath at 7:10AM (Akshudhita awastha), after this patient was made to take luke warm Milk - 2ltr (Akanthapana) at 7:19AM.

- At 7.26 AM, Vamana Yoga or Medicine was given to patient in Lehya form, i.e. Madhanphalapipalli Churna (Antar-nakha-musti-parmana) $=8 \mathrm{gm}$, Yastimadhu Churna $=4$ gm, Saindhava Lavana $=1$ gm and Honey = Quantity sufficient. The patient was observed until the appearance of 1st Vamana Vega, then 2 ltrs of Yastimadhu phanta was given from 7:37 AM and after this, 2 ltrs of Ushanodaka was given to patient from 7:48 AM. After the completion of Vaman Karma Dhoompana with Haridradi varti was given at 8:15AM.

- A Chart was maintained to note down Time of starting of Vegas, contents etc. in the below format.

TABLE 3-

\begin{tabular}{|c|c|c|c|c|c|c|c|c|}
\hline Time & $\begin{array}{l}\text { Name of the } \\
\text { drug }\end{array}$ & $\begin{array}{l}\text { Quanti } \\
\text { ty }\end{array}$ & Vega & $U p a$-vega & Output & $\begin{array}{l}\text { Sign, } \\
\text { Sympto } \\
\text { ms }\end{array}$ & Vitals & $\begin{array}{l}\text { Compli } \\
\text { cation } \\
\text { if any }\end{array}$ \\
\hline 7:10AM & Yavagu & $75 \mathrm{gm}$ & & & & & $\begin{array}{l}\text { Bp- } \\
130 / 90 \mathrm{mmHg} \\
\text { Pulse- } 74 / \mathrm{min}\end{array}$ & \\
\hline 7:19AM & Dugdha & 6 Glass & & 1 & Dugdha & & $\begin{array}{l}\text { Bp- } \\
130 / 80 \mathrm{mmHg} \\
\text { Pulse- } 76 / \mathrm{min}\end{array}$ & \\
\hline 7:22AM & “ & 2 Glass & 1 & & $\begin{array}{l}\text { Dugdha } \\
+ \text { kapha }\end{array}$ & & & \\
\hline 7:26AM & $\begin{array}{l}\text { Medicine- } \\
\text { Madhanphalapip } \\
\text { alli Churna) }=8 \\
\text { gm, Yastimadhu } \\
\text { Churna = } 4 \text { gm, } \\
\text { Saindhava } \\
\text { Lavana = } 1 \mathrm{gm} \\
\text { and Honey = } \\
\text { Quantity } \\
\text { sufficient }\end{array}$ & & & & & & $\begin{array}{l}\text { Bp- } \\
140 / 80 \mathrm{mmHg} \\
\text { Pulse-78/min }\end{array}$ & \\
\hline 7:32AM & & & & & & $\begin{array}{l}\text { Sweda- } \\
\text { pravarti }\end{array}$ & $\begin{array}{l}\text { Bp- } \\
\text { 140/90mmHg } \\
\text { Pulse- } 80 / \mathrm{min}\end{array}$ & \\
\hline 7:37AM & Yastimadhu fanta & 5 Glass & 1 & & $\begin{array}{l}\text { Dugdha } \\
\text { +kapha }\end{array}$ & & & \\
\hline 7:40AM & “ & 2 Glass & 1 & 2 & $\begin{array}{l}\text { Kapha+ } \\
\text { Fanta }\end{array}$ & & $\begin{array}{l}\text { Bp- } \\
\text { 140/90mmHg } \\
\text { Pulse-80/min }\end{array}$ & \\
\hline 7:42AM & “ & 1 Glass & & 1 & $\begin{array}{l}\text { Kapha+ } \\
\text { Fanta }\end{array}$ & & & \\
\hline 7:44AM & “ & 2 Glass & 1 & & $\begin{array}{l}\text { Kapha+ } \\
\text { Fanta }\end{array}$ & & $\begin{array}{l}\text { Bp- } \\
\text { 140/90mmHg } \\
\text { Pulse-84/min }\end{array}$ & \\
\hline $7: 45 \mathrm{AM}$ & “ & 1 Glass & & 1 & $\begin{array}{l}\text { Kapha+ } \\
\text { Fanta }\end{array}$ & & & \\
\hline 7:47AM & “ & 2 Glass & 1 & & Medicine & & $\begin{array}{l}\text { Bp- } \\
140 / 80 \mathrm{mmHg} \\
\text { Pulse- } 86 / \mathrm{min}\end{array}$ & \\
\hline
\end{tabular}




\begin{tabular}{|c|c|c|c|c|c|c|}
\hline 7:48AM & LavanAudak & 3 Glass & 1 & 1 & $\begin{array}{l}\text { Kapha+ } \\
\text { Fanta }\end{array}$ & $\begin{array}{l}\text { Bp- } \\
\text { 140/80mmHg } \\
\text { Pulse- } 88 / \mathrm{min}\end{array}$ \\
\hline 7:50AM & “ & 2 Glass & 1 & & $\begin{array}{l}\text { Fanta+ } \\
\text { yavagu }\end{array}$ & $\begin{array}{l}\text { Bp- } \\
140 / 90 \mathrm{mmHg} \\
\text { Pulse-88/min }\end{array}$ \\
\hline 7:52AM & “ & 2 Glass & 1 & 1 & $\begin{array}{l}\text { Lavanau } \\
\text { dak }\end{array}$ & \\
\hline 7:55AM & “ & 2 Glass & & 2 & $\begin{array}{l}\text { Lavanau } \\
\text { dak }\end{array}$ & $\begin{array}{l}\text { Bp- } \\
140 / 90 \mathrm{mmHg} \\
\text { Pulse-86/min }\end{array}$ \\
\hline 8:00AM & “ & 2 Glass & & 2 & $\begin{array}{l}\text { Lavanau } \\
\text { dak+pitta }\end{array}$ & $\begin{array}{l}\text { Bp- } \\
\text { 140/90mmHg } \\
\text { Pulse-86/min }\end{array}$ \\
\hline
\end{tabular}

- Paschat Karma: Samsarjana Krama advised as per Shuddhi attained, i.e. Samsarjana karma for 7 days was advised to the patient, which contains 3 Anna Kala. In 1st Anna kala Peya was advised. Gradually Ahara was changed (Laghu to Guru Guna Pradhana), finally normal diet was given in the evening of $7^{\text {th }}$ day.

TABLE-4: DISCHARGE ADVICE: (Shamanoushadhi was given from 24-3-2020 to 6-3-2020)

\begin{tabular}{|l|l|l|l|}
\hline Sr. & Medicine & Dose and Dosage & Duration \\
\hline 1 & Arogyavardhini vati & $2 \mathrm{TID} \mathrm{A} / \mathrm{F}$ & 15 days \\
\hline 2 & Panchatikta ghrita guggul & $2 \mathrm{TID} \mathrm{A} / \mathrm{F}$ & 15 days \\
\hline 3 & Gandhak rasayan & $2 \mathrm{TID} \mathrm{A} / \mathrm{F}$ & 15 days \\
\hline 4 & Manjistadi kashayam & $50 \mathrm{ml} \mathrm{BD} \mathrm{B/F}$ & 15 days \\
\hline
\end{tabular}

\section{Observations and Results}

\section{Observations on Vamana Karma}

$1^{\text {st }}$ Vega starts at 7:22 AM, last Vega i.e. $8^{\text {th }}$ Vega was observed at7:52 AM. Depending upon observation done during the whole procedure below findings were noted.

TABLE-5

\begin{tabular}{c|c|c|}
\hline $\begin{array}{c}\text { Sr. } \\
\text { no. }\end{array}$ & $\begin{array}{c}\text { Vamana } \\
\text { Karma } \\
\text { criteria }\end{array}$ & Remarks \\
\hline 1 & Vegiki & $\begin{array}{c}\text { Uttam shudhi } \text { attained (i.e. } 8 \\
\text { Vega observed) }\end{array}$ \\
\hline 2 & Lengiki & $\begin{array}{c}\text { Samyak Vamana Lakshan } \\
\text { observed }\end{array}$ \\
\hline 3 & Maniki & Madhyam $(10.5$ tr) \\
\hline 4 & Aantiki & Pittanta attained. \\
\hline
\end{tabular}

Observations on Signs and Symptoms Gradation Scales

Table-6: Aswedanam

Grade

Normal

Improvement

Present in Few Lesions

Present in All Lesions

Aswedanam in Lesion and Uninvolved Skin

Score

0

1

2

3

Table-7: Maha-Vastu

\section{Grade}

No Lesions on Mahasthanam

Lesion on partial parts of hand, leg, neck,scalp, back

Lesion on most parts of hand, leg, neck scalp,back
Lesion on whole part Mahasthanam (vast

area)

Lesion on whole body

4

Table-8: Scaling

Grade

No Scaling

Mild Scaling by rubbing/by itching

Moderate scaling by rubbing/by itching

Severe scaling by rubbing/by itching

Scaling without rubbing/by itching

Score

0

1

1

2

3

Table-9: Kandu

Grade

Score

No Itching

Occasional Itching

Frequent but tolerate itching

Very severe itching disturbing sleep and activity

Table-10: Daha

Grade

Score

Absent
Occasional
Frequent daha
After itching started
Continues daha

Occasional

After itching started

Continues daha

0

1

2

3

Table-11: Rukshata

Normal Skin

Grade

Score

Slightly dry skin

Excessively dry skin

Lichenified

Bleeding through the skin

0
1
2
3
4




\begin{tabular}{|l|c|}
\multicolumn{2}{c}{ Table-12: Vaivarna } \\
Grade & Score \\
\hline Normal discolouration & 0 \\
\hline Slight discolouration & 1 \\
Reddish discolouration & 2 \\
\hline Slight reddish black discolouration & 3 \\
\hline Black discolouration & 4 \\
\hline
\end{tabular}

Table-13: Pidaka

Grade Score

\section{Absent}

Disappears but discolouration persists

Pidaka in $<5$ sq.cms. in whole of the affected area

Pidaka in between 5-10sq.cms. in whole affected area

Many or uncountable pidaka in whole of the affected area

Score

2

Table-14: Vedana

\begin{tabular}{|c|c|}
\hline Grade & Score \\
\hline Absent & 0 \\
\hline Mild & 1 \\
\hline Moderate & 2 \\
\hline Severe & 3 \\
\hline
\end{tabular}

Table-15: Auspitz Signa and Candle Grease Sign Grade Score

\begin{tabular}{|l|c|}
\hline Absent & 0 \\
\hline Improvement & 1 \\
\hline Present & 2 \\
\hline
\end{tabular}

\section{TABLE-16:}

On the Basis of Result found during treatment, observations were quoted below,

\begin{tabular}{|c|c|c|c|c|}
\hline & $\begin{array}{l}\text { Before } \\
\text { Snehap } \\
\text { ana }\end{array}$ & $\begin{array}{l}\text { After } \\
\text { Snehap } \\
\text { ana }\end{array}$ & $\begin{array}{l}\text { After } \\
\text { Vama } \\
\text { na }\end{array}$ & $\begin{array}{l}\text { After } \\
\text { Samsar } \\
\text { jan } \\
\text { Karma }\end{array}$ \\
\hline Auspitz sign & 2 & 1 & 1 & 0 \\
\hline $\begin{array}{l}\text { Candle } \\
\text { grease sign }\end{array}$ & 1 & 1 & 0 & 0 \\
\hline PASI scoring & 6.6 & 5.4 & 2.4 & 0.8 \\
\hline $\begin{array}{l}\text { Matsyashklo } \\
\text { pam } \\
\text { (Scaling) }\end{array}$ & 3 & 2 & 1 & 0 \\
\hline $\begin{array}{l}\text { Mandloutpati } \\
\text { (patches) }\end{array}$ & 3 & 2 & 1 & 1 \\
\hline $\begin{array}{l}\text { Kandu } \\
\text { (Itching) }\end{array}$ & 3 & 2 & 1 & 1 \\
\hline $\begin{array}{l}\text { Rukshata } \\
\text { (Dryness) }\end{array}$ & 3 & 2 & 2 & 0 \\
\hline Vaivarnya & 3 & 2 & 1 & 1 \\
\hline
\end{tabular}

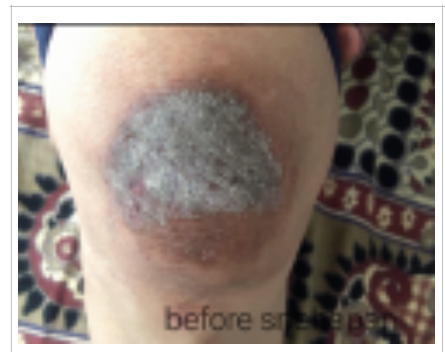

FIg 1: Before Snehapana (4-3-2020)

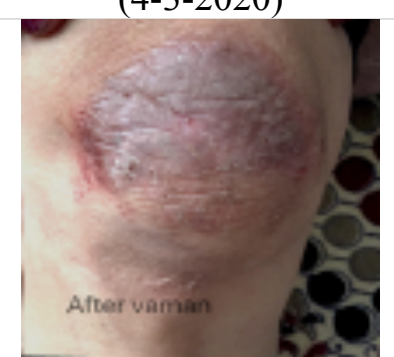

Fig 3: After Vaman Karma (16-3-2020)

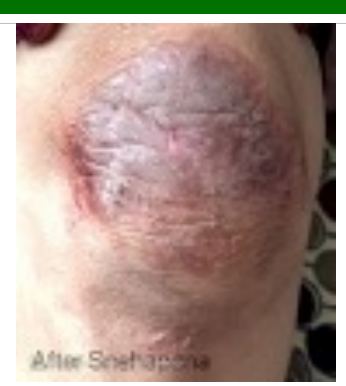

FIg 2: After Snehapana (14-3-2020)

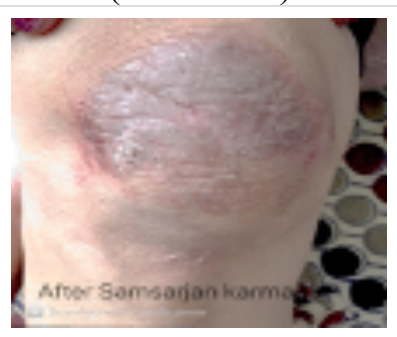

Fig 4: After Samsarjan Karma (23-3-2020)

\section{Discussion}

Psoriasis is a Papulo Squamous disorder of the skin, characterized by sharply defined erythematous squamous lesions. They vary in size from pinpoint to large plaques. At time, it may manifest as localized or generalized Pustular eruption.(9) Eka-Kushtha can be compared with Psoriasis, because the description and characteristic feature of it are similar with description of Psoriasis, i.e. Aswedanam (No sweatning) - The lesion of this disease are dry \& rough, Mahavastu (Large area) - Lesions are found all over the body, Matsya Shakalopamam (Scaly patches) -Well-defined raised macules, papules, erythematic plaques which are covered with silvery scales. Krishna Aruna varna erythematous lesion. It is counted as KshudraKustha(10). As it is a disease of Bahya rogamarga, so both Antahparimarjana (Internal) and Bahirparimarjana (External) treatments should be used. Considering the above facts, composite treatment plan was adopted. Initially Abhyantara Shodhana (Internal oleation) done with Vamana Karma and after completion of Samsarjana Krama (Dietery), Samshamana treatment was advised.

- Purva karma- The Purva Karma administered in the form of Deepana-Pachana and Snehapana. Purvakarma has the important action of separating the vitiated Doshas from the Dushyas i.e. Srotas in the body (Dosha-dushya samurchana). It also helps in bringing the vitiated Dosha from Shakha to the Koshtha area in the body from where these vitiated Dosha can be removed from the nearest root of the body(11).

- Abhyantra Snehapana: Abhyantara Snehapana (internal oleation) is the process of administration of Sneha internally employed for the purpose of Shodhana, Shamana and Brimhana. It is important here to understand the signs and symptoms of Samyak Snehana described by Acharyas i.e. Snehana indicates Snigdhata (unctuousness), Vishyandan (liquefication), 
Vilayana (dissolution or diffusion) Dalhanacharya while commenting quotes Vishyandanam Drava Srutihi, Mardavata means softness. Kleda is moistness or wetness. Here Kleda signifies the increase of Apya Guna in the body (12). Considering these Gunas as the primary features the assessment of Samyak Snigdha is done. Sneha can be considered by the unctuousness of the body, stool and skin (Pureesha Twak and Gatra Snigdhata). Vishyandana is witnessed by excretion of stool with or without Sneha, (Snigdha Mala and Adhastat Snehadarsana). Mardavata is assessed by Gatra Mardava. Kledana is assessed by sconsistency of stool i.e. Asamhat Varcha(13).

The Doshas present in the body has its own Gati, and in Vyadhita Avastha the Doshas will be aggravated and may be present in Shakhas (periphery). The Shodhana Chikitsa (Purification) aims at expulsion of this vitiated Doshas from the body either by Urdhwamarga (administering Vamana) or Adhomarga (administering Virechana)(14). Acharya Vagbhata in Doshopakramaniya has explained the causes for Dosha Gati. Vyayama (exercise), Ushma and Tikshnata of Jataragni (Digestive fire), Ahita Ahara Bhojana, vitiates the Vatadi Doshas and takes the Doshas to Shakhas from Koshta. These Doshas are brought back to Koshta by Srotomukha Vishodhana / Vivarana, Abhishyandi /making Dosha Dravibhuta, Paaka (bringing Pachana of the Dosha), which is well delivered by Snehana and Swedana Karmas(15). For the attainment of Shodhanaphala proper Snehapana is an essential factor which is directly dependent on $A g n i$ and Agnibala as a prime factor. Thus, assessing Agni is very essential before Shodhanartha Abhyantara Snehana. (16).

\section{- Pradhan karma -}

Vaman was performed as a pardhana karma here. Because Ek-kustha being Kapha Pradhana, Tridoshajavyadhi best treated by Shodhana procedure(17). Soothened Doshas will get liquefied and reaches to Koshtha by Swedana, which can be easily eliminated by the action of Vaman.(18). Shodhana (Vamana and Virechana) probably may leads to certain endogenous changes in the body responsible for the alleviation of psoriatic pathological process.

\section{- Samsarjanakrama-}

Samsarjan krama was carried out in the patient for 7 days/3 Aana kala considering the Pravara Shuddhi (Best shudhi). Due to shodhan agni got hampered So Samsarjana krama enhances ani as well as provide strength to the body after Vaman(19) Hence the patient was kept kept on laghu, pathyahar and discharged on 25-3-20.

\section{Internal Medications}

- Panchatiktaghrit Guggul: This is a very potent drug of choice in Kushtha Adhikar. It is indicated in Visham and Atiprabala Vata. Nimba, Guduchi, Patola, Kantakari, Vasa are the contents of Panch tikta (20). Here in Psoriasis though Kapha and vata are involved, to spread all these Doshas are carried by Vata itself. Tikta Rasa acts on both Vata and Kapha doshas.Guggulu is yogavahi dravya. Acts as Anti Itching property, Kled, Vikrut Meda upshoshana, Vranashodhaka (wound healing). (21)

- Aarogyavardhini Rasa: It is Herbomineralfomulations. It is having Kushtahara, Durmedahara, Kledahara, Dhatu Gata Amapachana, Raktaprasadana, and also having Dipana-Pachana and Kapha-Vata Shamaka property, all these qualities are very much helpful for Samprapti Vighatan of Kushta (22).

- Gandhak rasayan: It is having properties like Kushtagna, Rakta Doshahara, Vishaghna, Vranasodhana, Ropana, Rakta-Tvakgata Vishahara, Durmedhohara, Rasayana, Dhatubalya. all these properties are essential to treat EkaKushta(23).

- Manjistadi kashayam: This medicine is mainly used in treatment of various skin diseases. It also helps in natural purification of blood so can be used in skin related problems. Manjishtadi Kashayam helps in blood detoxification and also dissolves the obstructions in blood flow (24).

\section{Conclusion}

From this case report we may conclude that combined Ayurvedic treatment and diet regimen can be potent and effective in treatment of Ekakustha (Psoriasis). No adverse effect and aggravation of the symptoms was found in the patient during and after the treatment. The complete study with a larger sample size can be done to check the significant result on the disease as well as the Karma. Eka Kushta is a chronic and relapsing in nature, Acharya mentioned Puna Puna shodhana (Repeated Purification) for treating Kushta, hereafter Vamana Karma other Shodhana therapy like Virechana, Raktamokshana can be followed for better results.

\section{References}

1. Davidson's. Principles and practice of medicine. 21stedition. Churchill livin stone publication, 2010, Chapter - (Diseases of the skin) Pg-900.

2. Michael Hertl; Autoimmune diseases of skin; third edition; Springer Wein New York; pg. no. 328-331.

3. Pandit Kashinath Pandey and Gorakhnath Chaturvedi;Charak Samhita, Savimarsha VidyotiniHindi Vyakhya;Varanasi; Ed 2011;PubChaukhamba Sanskrit Sansthana Chikitsa sthan.7.Pg no117

4. Sunil Dogara,Psoriasis:Epidemioloy, Clinical features, Co-morbities, and Clinical scoring, Indian dermatology online journal,1 Nov 2016,Pg no:471-480

5. Pandit Kashinath Pandey and Gorakhnath Chaturvedi;Charak Samhita Chikitsa sthan.7, Savimarsha Vidyotini-Hindi Vyakhya;Varanasi; Ed 
2011;Pub-Chaukhamba Sanskrit Sansthana.Pg no.712

6. Pandit Kashinath Pandey and Gorakhnath Chaturvedi;Charak Samhita . Chikitsa sthan.7, Savimarsha Vidyotini-Hindi Vyakhya;Varanasi; Ed 2011;Pub-Chaukhamba Sanskrit Sansthana.Pg no712

7. PASI Calculator- http;//pasi.corti.li/

8. Neena Khanna; Illustrated synopsis of Dermatology and Sexually transmitted diseases; Ed 2005; Peepee publishers and distributors; Pg. no. 38.

9. Pandit Kashinath Pandey and Gorakhnath Chaturvedi;Charak Samhita Chikitsa sthan.7, Savimarsha Vidyotini-Hindi Vyakhya;Varanasi; Ed 2011;Pub-Chaukhamba Sanskrit Sansthana. Pg no 854.

10. Vasant C patil; Principles and practices of Panchakarma, chapter-7. PublicationChaukhambha Sanskrit Sansthana. Pg no 104.

11. Sushruta,Sushrut Samhita, edited by Ayurved Tattva Sandipika,by Ambika Dutta Shastri,Chaukhamba Sanskrit Sansthan, Varanasi,part 1,2015, p-319.

12. Charak Samhita of Agniuvesa, by Kashinath Shastri,part 1, 2016, chaukhamba, Varanasi p-775.

13. Pandit Kashinath Pandey and Gorakhnath Chaturvedi;Charak Samhita Kalpa Sthana-1chp, Savimarsha Vidyotini-Hindi Vyakhya;Varanasi; Ed 2011;Pub-Chaukhamba Sanskrit Sansthana.Pg no 712.
14. Pandit Kashinath Pandey and Gorakhnath Chaturvedi;Charak Samhita Sutra Sthan-13chp, Savimarsha Vidyotini-Hindi Vyakhya;Varanasi; Ed 2011;Pub-Chaukhamba Sanskrit Sansthana .Pg no 854.

15. Pandit Kashinath Pandey and Gorakhnath Chaturvedi;Charak Samhita Chikitsa sthan.7, Savimarsha Vidyotini-Hindi Vyakhya;Varanasi; Ed 2011;Pub-Chaukhamba Sanskrit Sansthana.Pg no.456.

16. Pandit Kashinath Pandey and Gorakhnath Chaturvedi;Charak Samhita Sidhi Sthana-1chp, Savimarsha Vidyotini-Hindi Vyakhya;Varanasi; Ed 2011;Pub-Chaukhamba Sanskrit Sansthana .Pg no 712.

17. Jatinder Verma, Importance of Samsarjana Karma after Samshodhana Karma: A review, IJAHM 8:5(2018) 3048-056.

18. Sushruta,Sushrut Samhita, edited by Ayurved Tattva Sandipika,by Ambika Dutta Shastri,Chaukhamba Sanskrit Sansthan, Varanasi,part 1,2015, p-37.

19. Priyavat Sharma, Charak Samhita Chikitsa Sthana 7/16, Pub-Chaukhamba Sanskrit Sansthana,2th edition 1994. Pg.456.

20. Shafer . v, M. (2014). Samhita of Ayurvedic medical specialities (3rd ed). Tamil Nadu: Dr Y.Mahadeva Iyer's Srisarada Ayurveda Hospital.Pg no 363.

21. Shafer . v, M. (2014). Samhita of Ayurvedic medical specialities (3rd ed.). Tamil Nadu: Dr Y.Mahadeva Iyer's Srisarada Ayurveda Hospital . Pg 362. 